\title{
The Internalization and Implementation of Minangkabau Alternative Leadership Values for Formal and Informal Leaders in Padang
}

\author{
Sulastri ${ }^{1}$, Yuki Fitria ${ }^{2}$, Chichi Andriani ${ }^{3}$, Mega Asri Zona ${ }^{4}$ \\ ${ }^{1}$ Dept. of Management, Faculty of Economics, Universitas Negeri Padang, Padang Indonesia \\ $\square$ (e-mail) sulastri_feunp@yahoo.com \\ ${ }^{2}$ Dept. of Management, Faculty of Economics, Universitas Negeri Padang, Padang Indonesia \\ $\triangle$ (e-mail)yuki.fifit@gmail.com \\ ${ }^{3}$ Dept. of Management, Faculty of Economics, Universitas Negeri Padang, Padang Indonesia \\ $\triangle$ (e-mail) chichi.andrianiunp@gmail.com \\ ${ }^{4}$ Dept. of Management, Faculty of Economics, Universitas Negeri Padang, Padang Indonesia \\ $\triangle$ (e-mail) megaasrizona@gmail.com
}

\begin{abstract}
The objectives of this research are 1) to conceptualize Minangkabau alternative leadership, and 2) to find out the level of knowledge and understanding of the formal and informal leaders in Padang about the Universal Leadership Model of Minangkabau. The population of this research is formal leadership practitioners who represented by community bureaucrats and informal leadership practitioners represented by ninik mamak (traditional leaders), the Islamic scholars (ulama) and intellectuals in Padang. Data were collected through questionnaires, focus group discussions (FGDs), expert discussions and regular meetings. The obtained data were then analyzed using variance test with variance analysis technique (ANOVA). The collected data were also analyzed and discussed using a qualitative approach. Through the process of focus group discussion (FGD), expert discussion, regular meetings, language considerations, research scope, retrieval fluency, representation of contents, and aesthetic reasons, the research team decided that the term "Minangkabau Alternative Leadership" is changed into the "Universal Leadership Model of Minangkabau". The results of data processing with variance test, it is found that there are significant differences in knowledge before and after the FGD implementation on formal and non-formal leaders in Padang related to the Universal Leadership Model of Minangkabau.
\end{abstract}

Keywords: formal leadership, informal leadership, Minangkabau traditional leadership

\section{Introduction}

The Minangkabau community's territory is on the province of West Sumatra with its baseline custom of "adat basandi syarak-syarak basandi kitabullah" (ABS-ABK) [Custom should be based on sharia and sharia should be based on the Quran], a custom recognized as a universal essence. Generally, in their way of living, they have the characteristics of democratic, receptive, egalitarian, centrifugal, competitive, cooperative society and mostly accommodate conflict (Naim, 2010). the Minangkabau culture covers a wider area, including "the rantau" areas of Minangkabau community such as Jambi, Riau and even the Malaya peninsula.

The traditional Minangkabau community lives in a region called the nagari which consists of tribes, "the kaum" and "the paruik" (limited relatives in matrilineal line), and has the political, economic and socio-cultural authorities over the society (Naim, 2007). The nagari is characterized by an agrarian rural area and unified through matrilineal lineages or by female lineage. Each of "the paruik", "the kaum" and the tribe is led by mamak, penghulu or datuk orwhich are known as "the ninik mamak", who are customarily responsible for leading their children and nephews. In addition, the nagari is also led by the Islamic scholars and the intellectuals who are authorized to direct the villagers in the domain of tawheed and science. The leadership model is known as the leadership of the tungku tigo sajarangan-tali tigo sapilin, where the tungku tigo sajarangan (TTS1) refers to actors or the 
leadership of ninik mamak, the Islamic scholars and the intellectuals, while the tali tigo sapilin (TTS2) symbolizes the custom values, the religion values and the scientific values. Furthermore, the nagari, as the smallest formal governmental unit within the territory of the united provinces of Republic of Indonesia, is led by a wali nagari which is equivalent to a village head in an urban area and represents the bureaucrat leadership.

The transformation in social, cultural and economic fields triggered by relatively massive changes in technology, information and communications, have created new wave of development which transformed the villages into urban areas in West Sumatra. The urban area is generally inhabited by Minangkabau tribes, indigenous people, immigrants from the surrounding areas and immigrants from outside Minangkabau tribe. This condition has an impact on the community order of the urban itself where the neighborhood is no longer unified by matrilineal lineage, but is unified through hierarchical institutions, ranging from neighborhood units (RT), community units (RW), district, subdistrict and city. This condition is relatively different from the nagari where the collective life is tied based on the familial system through the paruik, tribe and nagari.

Transformation occurs in Minangkabau society, especially in urban areas, and it either directly or indirectly has an impact on the conception and the implementation of the leadership of tungku tigo sajarangan-tali tigo sapilin (TTS1-TTS2). In the traditional community of Minangkabau, the leadership of ninik mamak is run by mamak, penghulu or datuak from matrileneal lineage from generations to generations. In contrast, the phenomenon does not exist in urban context, especially for the migrants. In addition, some writers such as Naim (2007), Gani (2002), and Gani (2011) also raised the issue on the TTS1-TTS2 leadership. Naim (2007) observed that in the context of the present governance system or the leadership of the nagari or district, there is an ambiguity on the roles and functions of ninik mamak, the Islamic scholars and the intellectuals. Furthermore, Gani (2002) has found the problems and the patterns of interaction ambiguity in the leadership of tungku tigo sajarangan which were caused by the independent but interrelated tasks that each element or the actors of leadership has. This condition often leads into conflict between the previously stated elements, so the researchers suggest the need for essential ideas and concepts of tungku tigo sajarangan leadership that can be implemented by an ideal leader.

To answer these problems, Sulastri and Andriani (2013), Sulastri et al. (2015) have conducted a two-stage study with the objective of identifying and modeling the leadership values of TTS1-TTS2 in Padang as a representation of urban areas of Minangkabau. Given that research is conducted in plural and multiplex urban society, the taxonomic identification of leadership conceptions does not only used TTS1-TTS2 leadership values, but also supplemented by transformational leadership values. The values are confirmed by Bass and Riggio (2006) as leadership models that prevails universally and accommodate values of idealized influence, inspirational motivation, intellectual stimulation, and individual consideration.

The objectives of this research are as follows. First, to conceptualize the alternative leadership Minangkabau. Second, to find out the level of knowledge and understanding of the formal and informal leaders in Padang on the Minangkabau Universal Leadership Model. At the first stage of the study, based on the collected and processed data using explanatory factor analysis, there are ten dimensions obtained as a leadership characteristic of the Minangkabau urban community. The ten dimensions are called as the Minangkabau Alternative Leadership, which consists of (1) preserving the legacy, (2) maintaining the dignity of the nephews/ society, (3) modeling, (4) guiding into tawheed, (5) applying science, (7) charismatic, (8) visionary, (9) inspirational and (10) kinship.

Furthermore, the second stage of study (Sulastri et al., 2015) has the objective of creating a model for the Minangkabau Alternative Leadership based on the ten dimensions for each actor of the leadership: the ninik mamak, the Islamic scholars and the intellectuals (as representation of non-formal leaders) and bureaucrats (as representation of formal leaders). It was found that the ten dimensions of leadership obtained in the first stage are the factors that form the formal and informal leadership in 
urban areas of Minangkabau, especially in Padang. This means that the Minangkabau leadership values not only can be implemented through collective leadership (ninik mamak, The Islamic Scholars and the intellectuals and bureaucrat) but can also be implemented in individual leadership. Individual leaders, both formal and non-formal, could use these ten dimensions in their leadership tasks. Thus, this study answered the problem of interaction and communication between the elements of tungku tigo sajarangan, as proposed by the study of Gani (2002) to create an ideal leader that implements the values of custom, religion, and science.

The ten dimensions of the Minangkabau Alternative Leadership have been proven to form the leadership of TTS1-TTS2, but in its application, four dimensions are applied in the same way and six dimensions are applied in a different way by each agent or element of leadership. Dimensions that are applied in the same way by both formal and informal leadership elements include preserving mutual legacy, charismatic, inspirational and visionary, while the dimensions applied differently are of protecting honor, applying science, building tawheed, developing science, modeling and kinship. These findings indicate that even though the four elements or agents of leadership in the study implemented the ten dimensions of the Minangkabau Alternative Leadership, each group applied it differently.

The implementation and application of Minangkabau Alternative Leadership based on TTS1-TTS2 and transformational leadership needs to accommodate the objective of ten dimensions in effective ways. Therefore, the ten dimensions need to be internalized by leaders and prospective leaders both in formal and informal leaders in Minangkabau urban areas, especially Padang. Intensive and comprehensive internalization will, in turn, leads to the implementation or practice of a culture-based leadership that complements the modern leadership values, and it could be accomplished effectively. Furthermore, a powerful conception of Minangkabau Alternative Leadership is also needed. So, it could be learned, shared and transferred from time to time by the Minangkabau community themselves, both territorially and culturally. It would also possible to be applied universally as the essence of Minangkabau culture and become a reference of transformational leadership.

Given that the leadership of TTS1-TTS2 is not completely an alien concept to the Minangkabau's community, the concept's internalization is performed through brainstorming on the focus group discussions, the expert discussions and the regular meetings. Therefore, the study is oriented more on action research, where the results are expected to increase the knowledge and ability of leaders and prospective leaders, and the Minangkabau community could preserve and practice their culture adaptively as one of the characteristics of the culture in general.

As an urban area with strong ABS-ABK culture and a persistent TTS1-TTS2 leadership model, Padang should possess special characteristics in order to adjust with the dynamics of urban community. These adjustments should not remove the core characteristics from its cultural roots as the Minangkabau community itself and could accommodate the changes in internal and external environment wisely. Likewise, leadership as one of the institutions of living society requires adjustment in accordance to the needs and the development of the society.

The need for such adjustments is being answered through the concept of the Minangkabau Alternative Leadership with the ten dimensions described previously. The problems that arise and need to be addressed include to what extent the leaders, prospective leaders and Minangkabau society are acquainted with and understand the concepts and have the ability to apply these Minangkabau Alternative Leadership dimensions in their leadership practice.

\section{Minangkabau Alternative Leadership}

The theory of Minangkabau leadership through the concept of tungku tigo sajarangan is formulated from generation to generation based on the experience and the reality of the living order of the Minangkabau society. Based on the results of the study conducted by Sulastri and Andriani (2013), 
from all these leadership concepts, specifics dimensions and subdimensions of leadership for Minangkabau urban areas are described in Table 1.

Table 1 Dimensions and sub-dimensions of Minangkabau Alternative Leadership

\begin{tabular}{ll}
\hline Construct & $\begin{array}{l}\text { Conceptual } \\
\text { Dimension }\end{array}$ \\
\hline $\begin{array}{l}\text { Leadership based on } \\
\text { custom values / }\end{array}$ & $\begin{array}{l}\text { Preserving } \\
\text { mutual } \\
\text { leadership of ninik } \\
\text { mamak }\end{array}$ \\
legacy/inheritance
\end{tabular}

Study Result Sub-dimension

Dimension

1. Preserving mutual legacy/ inheritance a. Preserving mutual legacy

b. Increasing mutual legacy

c. Utilization of mutual legacy

d. Resolving a dispute over misuse of mutual legacy

e. Providing sanctions for misuse of mutual legacy

f. Creating rules for the use of mutual legacy

a. Lending an ear for complains of nephews / society

b. Protecting the dignity of the nephews / society

Leadership based on Modeling religious values /

3. Modeling nephews / society

a. As the imam in the mosque.

b. As the ustadz at the leadership mosque

\begin{tabular}{|c|c|}
\hline $\begin{array}{l}\text { Guidance of } \\
\text { tawheed } \\
\text { (monotheism) } \\
\text { and worship }\end{array}$ & $\begin{array}{l}\text { 4. Guiding in } \\
\text { tawheed } \\
\text { (monotheism) } \\
\text { and worship }\end{array}$ \\
\hline
\end{tabular}

a. Comprehending the duties as suluah bendang dalam nagari (the torch of enlightenment) in the nagari

b. Fostering community worship

c. Building tawheed

K Leadership based
on
Science/Intellectuals
Leadership

$\begin{array}{ll}\begin{array}{l}\text { Science } \\ \text { Development }\end{array} & \text { 5. } \begin{array}{l}\text { Developing } \\ \text { science }\end{array}\end{array}$

a. Identifying science mastery

b. Developing Science

c. Empowering Science in community

\begin{tabular}{lll}
\hline Science & 6. & $\begin{array}{l}\text { Applying } \\
\text { science }\end{array}$ \\
Application &
\end{tabular}

a. Applying science in decision making

b. Applying science for community interest

\begin{tabular}{|c|c|c|c|c|c|}
\hline \multirow[t]{3}{*}{$\begin{array}{l}\text { K Leadership based } \\
\text { on Transformational } \\
\text { values }\end{array}$} & $\begin{array}{l}\text { Idealized } \\
\text { Influence }\end{array}$ & 7. & $\begin{array}{l}\text { Charismatic } \\
\text { traits }\end{array}$ & & $\begin{array}{l}\text { Emotional bonding } \\
\text { Becoming the pride and } \\
\text { the idol of community }\end{array}$ \\
\hline & $\begin{array}{l}\text { Inspirational } \\
\text { Influence }\end{array}$ & 8. & Visionary traits & a. & $\begin{array}{l}\text { Formulating vision and } \\
\text { mission } \\
\text { Determining clear and } \\
\text { reasonable target }\end{array}$ \\
\hline & $\begin{array}{l}\text { Intellectual } \\
\text { Stimulation }\end{array}$ & 9. & $\begin{array}{l}\text { Inspirational } \\
\text { traits }\end{array}$ & a. & $\begin{array}{l}\text { Discussing common } \\
\text { goals }\end{array}$ \\
\hline
\end{tabular}




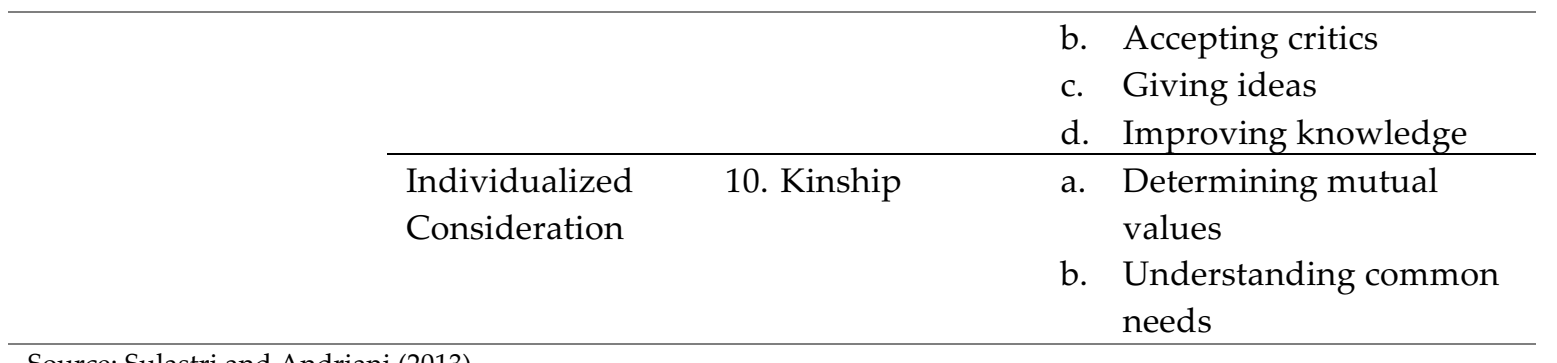

Source: Sulastri and Andriani (2013)

Based on the theoretical study and the results of previous research, there are ten leadership concepts that could be applied by leaders in Minangkabau area (Table 1). In the results of the leadership of tungku tigo sajarangan, the main task of the ninik mamak refers to the values of adat (tradition), the main task of the Islamic scholars refers to religious values, and the intellectuals' task refers to the values of science. As for the concept of transformational leadership developed based on the theory proposed by Bass (in Luthan and Doh, 2012), the main tasks are grouped into individual influence, inspirational motivation, intellectual stimulation and individualized consideration.

With the concept of the ten values of leadership, the leadership of the tungku tigo sajarangan is expected to be applicable universally, as it is in line with the Minangkabau culture that implements the universal concept of "alam takambang jadi guru" [learning from the nature] (Abraham, 2010). This is deemed possible because the values found are also equipped with transformational leadership values stated as effective and universally applicable (Luthan and Doh, 2012). In addition, these findings could answer the discourses and questions on the implementation of the leadership of tungku tigo sajarangan as proposed by previous research (Sulastri and Andriani, 2013).

According to Sulastri and Andriani (2013), the ten values of leadership found in their research are expected to completely represent the values of the leadership of Tungku Tigo Sajarangan. With these leadership values supplemented with transformational leadership values, every leader could conduct his leadership effectively.

Among the ten dimensions of Minangkabau leadership above, it is also found that generally there is no difference between the concept of leadership performed by formal leaders (bureaucrats) and informal leaders (ninik mamak, the Islamic scholars and the intellectuals). The difference only occurs in the application of leadership (Sulastri et al., 2015). The results of the study are four non-differentiated variables, namely preserving mutual legacy, charismatic traits, inspirational traits and visionary traits. Whereas, the other six variables are the differentiated variables, namely preserving common honor, applying science, modeling, developing science, fostering monotheism and kinship.

The above descriptions show that the leadership values of tungku tigo sajarangan still exist and are used in Minangkabau urban communities. In addition, the development of modern leadership concepts as represented by transformational leadership could be implemented in harmony and complementarily by formal and non-formal leaders (Sulastri, et al., 2015).

\section{Conceptual Framework}

This study is based on the leadership concepts that have been developed by some experts and researchers. Based on the study results conducted by research team, the conceptual framework of this study can be illustrated in Figure 1. 


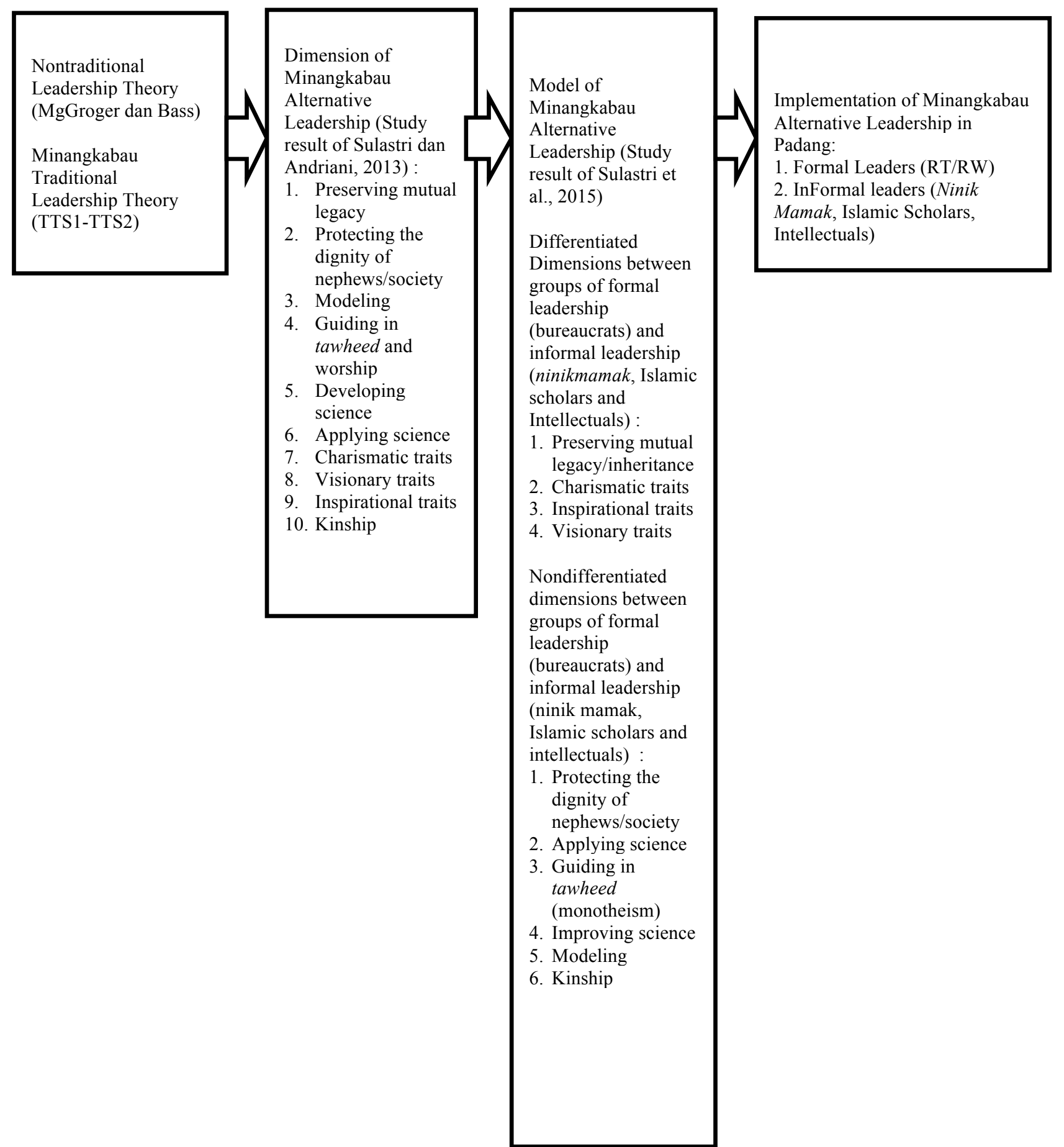

Figure 1 Conceptual framework of the research

\section{Methods}

The research population was the practitioners of formal or informal leadership in Padang. Formal leaders are community leaders based on formal regulation in the territory of Republic of Indonesia, namely RT and RW; while non-formal leaders are the leaders of tungku tigo sajarangan which are ninik mamak, the Islamic scholars and the intellectuals. The formal and informal leaders are chosen from one sub-district, Padang Utara sub-district, to represent the four sub-districts in the center of the city, and from eleven augmented sub-districts of the seven sub-districts in Padang, two sub-districts chosen are the Koto Tangah and Bungus Teluk Kabung sub-districts. 
From each of the sub-districts sample, there are 40 respondents employed in this study that consisted of 10 samples representing the leadership of ninik mamak, 10 samples representing the Islamic scholars, 10 people representing the intellectuals and 10 bureaucrats representing formal leaders.

Several data collection technique used in this study includes:

1. Questionnaire. The questionnaires were provided 3 times to the sample, i.e. before the FGD activity, during the FGD and after the FGD.

2. Focus Group Discussion (FGD). At the first year of FGD activities, the research team and the samples hold a meeting to discuss the leadership concepts as practiced by the samples. The FGD activities were conducted in each sub-district of the sample for one time.

3. Expert Discussion. This activity conducted discussion with leadership experts, the formal leadership (bureaucrat) experts and non-formal leadership experts (tungku tigo sajarangan). This activity was conducted once at Universitas Negeri Padang.

4. Regular Meeting. In this activity, the research team regularly conducted meetings to formulate research findings and reflections on findings for subsequent FGD activities.

Data were collected through a questionnaire which was developed from the concept of Minangkabau Alternative Leadership. The activities of FGD, expert discussions and regular meetings were conducted to see how far each leader has the opportunity to implement the concepts of Minangkabau Alternative Leadership before and after the research.

To analyze the data which has been collected through questionnaire, the first step was conducting the validity and reliability test using Cronbach alpha (cut off 0.6) developed based on conceptual theory. After the validity and reliability tests were done, variance test using analysis of variance technique (ANOVA) was done with the significance level of 0.05 . The analysis of variance (ANOVA) was conducted in two stages: before the FGD and after the FGD activity.

\section{Results and Discussion}

\section{The concept of the Model of Minangkabau Leadership}

The objective of this study needs to be re-formulated from the first objective in this study, which is to conceptualize the Minangkabau Alternative Leadership. Based on the research findings on taxonomy analysis of Minangkabau leadership in 2013, it still requires a standardized concept and terms and it should fulfill scientific rules and requirements. The concept of the leadership model is designated into two things due to its name and the ten dimensions of the model of Minangkabau Alternative Leadership identified in the previous study.

Due to the name of the leadership model used as Minangkabau leadership formulation, we previously called it the Minangkabau Alternative Leadership. As highlighted before, the model of Minangkabau Alternative Leadership was a leadership model we coined through the research in 2013 and 2015. The term "alternative" means that the conditions of the Minangkabau community have been transformed; however, the values of tungku tigo sajarangan and tali tigo sapilin (TTS1- TTS2) still strongly colored by the patterns of leadership in Minangkabau community. So, it will need adjustments enriched by the modern leadership model. On several occasions, we received comments from various parties about the term "alternative" we embedded, including from the intellectuals who acted as reviewers of our second research proposals; from the practitioners such as the ninik mamak, the Islamic scholars, the intellectuals and bureaucrats who also commented about the terms "alternative" which feels less representative, since it reflects the model as a choice or a substitute to the main model of leadership.

The process of conception and invention of the name was expected to represent the essence of the model and the dimensions of the findings. The conception process was made through focused discussion (focus group discussion-FGD) and expert discussions and regular meetings. Focused 
discussions were conducted in each research area with the discussion participants consisted of the ninik mamak, the Islamic scholars, the intellectuals and bureaucrats in that region. Most of the participants were those who had been involved in previous research. Meanwhile, the expert discussions were held at one place in the Universitas Negeri Padang, attended by delegations from three research areas which assumed to have the competencies as observed by the research team on FGD activities. Periodic meetings were conducted by the research team to discuss the results and findings obtained on activities of FGD and Expert Discussion and it is used as a reflection and interpretation of the data, especially on the obtained qualitative data.

Under the direction of the research team, through brainstorming process, the participants of Expert discussion were asked to submit a name which assumed to be appropriate, to change the terms alternative as used on the leadership model previously proposed. Based on suggestions of the participants on expert discussion activities, the research team conducted a regular meeting to discuss proposals concerning the name or term to replace the terminology of the Minangkabau Alternative Model. Considering the proposed name or term recommended on expert discussions and on the results of discussion at regular meetings, the language considerations, the research scope, ease of retrieval, content representation, and aesthetics reason, the research team decided that the name of Minangkabau Alternative Leadership model was replaced by the Minangkabau Universal Leadership model.

In the third stage of the research, the dimensions and sub dimensions of the Minangkabau Universal Leadership model that have been constructed in the previous research, are enhanced through the terms that used for its dimensions and sub dimensions. The objective was to meet the scientific requirements of which a term should at least meet the requirements of original, concise, provocative and relevant characteristics. Therefore, the process of conception of dimensions and sub dimensions were made through focused discussion activities, expert discussions and periodic regular meetings involving the ninik mamak, the Islamic scholars, the intellectuals, the bureaucrats and the research team. The results of the discussions on the three activities was that the participant agreed and comprehended each dimensions and sub dimensions that have been formulated, so the formulation or conception is only related to the enhancement of used terms.

\section{Results of Analysis of the Level of Knowledge and Comprehension of the Formal and Informal Leaders toward the Minangkabau Universal Leadership Model in All Sub-districts}

From all samples in three sub-districts, One Way ANOVA test was performed to find out whether there was a difference in the knowledge and understanding of the formal and informal leader of universal leadership model before and after FGD. The test requires data to be normally distributed. However, since the data are not normally distributed, they were then analyzed with nonparametric test with Kruskal-Wallis test approach. The test results are presented in Table 2.

Table 2 Statistical Test Values

\begin{tabular}{ll}
\hline & 10 Dimensions \\
\hline Chi-square & 348,230 \\
df & 3 \\
Asymp. Sig. & 0.000 \\
\hline \multicolumn{2}{l}{ Source: Results of Primary Data Processing (2017) }
\end{tabular}

From table 2 above, it can be seen that the statistical test value of Chi-square is 348,230 with the significance level $0.000<0.05$. This means that there is a difference in the knowledge and comprehension of the formal and informal leaders in Padang about the Minangkabau Universal Leadership Model, which is significant before and after the FGD conducted. Thus, the results support the first hypothesis, that there is a significant difference on the leaders' knowledge before and after the FGD on the Minangkabau Universal Leadership Model. This could indicate that by conducting the FGD activities, the formal and informal leaders in Padang enhanced and increased their 
knowledge and understanding about the ten dimensions of the Minangkabau Universal Leadership Model. Basically, all dimensions of the values were already known and applied by the formal and informal leaders in Padang. Since the 10 dimensions are derived from the values of the leadership of the tungku tigo sajarangan, with the main tasks of the ninik mamak as the leader of Minangkabau traditions, the Islamic scholars as the religious leader and the intellectuals as the leader of intellectuals. This model is then complemented by the values of transformational leadership.

\section{Conclusions}

From the study results, it can be concluded that the Minangkabau Alternative Leadership Model found through the research in 2013 and 2015, here in after is referred to as the Minangkabau Universal Leadership Model. Based on test results on the 10 dimensions formulated in the model of Minangkabau Universal Leadership applied to the FGD participants, it was found that there is a significant difference in knowledge on Minangkabau Universal Leadership Model between formal and informal leaders in Padang, based on the test done before and after conducting the FGD.

\section{Acknowledgments}

We would like to show our gratitude to the Indonesian Ministry of Research, Technology and Higher Education for funding this research.

\section{References}

Bass, B. M., \& Riggio, R . E. (2006). Transformational Leadership. Second Edition. New Jersey: Lawrence Erlbaum Associates Inc.

Fatimah, S. (2010). Kepemimpinan tradisional masyarakat Minangkabau pada masa kependudukan Jepang. Tingkap, VII (1).

Gani, R. (2002). Tungku Tigo Sajarangan, analisis model komunikasi kelompok dalam interaksi pemimpin pemerintah di Sumatera Barat. Thesis. Universitas Padjajaran, Bandung.

Gani, R. (2011). Filosofi Tungku Tigo Sajarangan dalam Sistem Pemerintahan Sumatera Barat. Jurnal Penelitian. Menggapai Pencitraan Berbasis Kearsipan Lokal.

Ilham, M., \& Ramli, R. (2011). Kepemimpinan Minangkabau: Aspek teoritis. Jurnal Kumpulan Peneliti dan Pelaku Sosial dan Budaya. Retrieved from http://www.google.com on 15 February 2013.

Ilyas, A. (2010). Nan empat, dialektika, logika, sistematika alam terkembang. Lembaga Kekerabatan Datuk Soda.

Luthans, F., \& Doh, J. P. (2012). International Management Culture, Strategy and Behavior. Seventh Edition. Mc-Graw-Hill International Edition.

Mauludin, M. A. (2010). Tinjauan sosiologi pedesaan dalam perspektif struktur dan organisasi sosial atas kepemimpinan tokoh adat dan panutan masyarakat Minangkabau. Fakultas Peternakan. Universitas Padjajaran, Bandung.

Naim, M. (2007). Kumpulan karangan Mochtar Naim 1960-2012. Retrieved from http://www. google.com on 30 November 2013.

Naim, M. (2010). Kumpulan karangan Mochtar Naim 1960-2010. Retrivied from http://www.google.com on 29 November 2013.

Sulastri, \& Andriani, C. (2013). Analisis taksonomi nilai-nilai kepemimpinan Minangkabau: Studi kasus pada wilayah perkotaan Sumatera Barat. Laporan akhir tahun penelitian hibah bersaing.

Sulastri, Andriani, C., \& Fitria, Y. (2015). Faktor-faktor yang membentuk kepemimpinan formal dan nonformal berbasis budaya Minangkabau di Kota Padang. Laporan akhir tahun penelitian fundamental.

Yunus, Y. (2009). Peningkatan peran ninik mamak dalam penerapan filosofi ABS. Retrieved from http:// www.google.com on 20 January 2013. 